\title{
Retraction Note to: "Global Assessment in the World Bank Education Strategy 2020"
}

\author{
Christopher S. Collins ${ }^{\mathrm{a}, *}$ \\ ${ }^{\mathrm{a} A z u s a}$ Pacific University, USA
}

\section{Retraction Note \\ Excellence in Higher Education}

June 2011, Volume 2, Issue 1, pp 29-41

The online version of the original article can be found under doi:10.5195/ehe.2011.41.

This article published in Volume 2, Issue 1, pages 29-41 (DOI 10.5195/ehe.2011.41) has been retracted at the request of the editors. The editors became aware of the issue on 21 March 2016 and quickly began investigating the situation. Several locations in the article contain plagiarized texts from various authors, either with inadequate or no attribution. Specifically, these include: excerpts from Marilee J. Bresciani's 2006 book Outcomes-Based Academic and Co-Curricular Program Review: A Compilation of Institutional Practices appearing on page 30; excerpts from Tom Schuller and Stéphan Vincent-Lancrin's chapter in the 2009 book International Organizations and Higher Education Policy: Thinking Globally, Acting Locally? appearing on page 31; excerpts from the Organisation for Economic Co-operation and Development (OECD) website "UNESCO, OECD guidelines for quality provision in cross-border higher education" appearing on page 31; excerpts from David H. Kamens and Connie L. McNeely's 2010 article, "Globalization and the Growth of International Education Testing and National Assessment" published in the Comparative Education Review appearing on page 31, and; excerpts from E. J. K. McKellar's conference paper "Change our assessment practices? Why should we? The theory behind assessment practices" appearing on pages 32-33. The author apologizes to the journal and to its readers for the errors noted above.

\section{References}

Bresciani, Marilee J. 2006. Outcomes-Based Academic and Co-Curricular Program Review: A Compilation of Institutional Practices. Sterling, VA: Stylus Publishing.

Kamens, David H., and Connie L. McNeely. 2010. "Globalization and the Growth of International Educational Testing and National Assessment," Comparative Education Review 54 (1): 5-25.

McKellar, E. J. K. 2002. "Change our assessment practices? Why should we? The theory behind assessment practices." Available online at: http://www.leeds.ac.uk/educol/documents/00002239.htm; accessed on 12 April 2016.

Organisation for Economic Co-operation and Development (OECD). 2005. UNESCO, OECD guidelines for quality provision in cross-border higher education. Paris: OECD. Available online at: http://www.oecd.org/general/unescooecdguidelinesforqualityprovisionincross-borderhighereducation.htm; accessed on 12 April 2016.

Schuller, Tom, and Stephan Vincent-Lancrin. 2009. "OECD Work on the Internationalization of Higher Education: An Insider Perspective." In International Organizations and Higher Education Policy: Thinking Globally, Acting Locally?, edited by Roberta Malee Bassett and Alma Maldonado-Maldonado (pp. 64-81). New York: Routledge.

*Address: Department of Higher Education, Azusa Pacific University, 901 E. Alosta Ave., P.O. Box 7000 Azusa, CA 91702, USA; Email: christopher.s.collins@gmail.com.

(«) EYसAC-MD This work is licensed under a Creative Commons Attribution-Noncommercial-No Derivative Works 3.0 United States License. ISSN 2153-9669 (print) 2153-9677 (online) | doi: 10.5195/ehe.2016.148 | http://ehe.pitt.edu 